\title{
Isoforms of Nitric Oxide Synthase in the Pig Testis
}

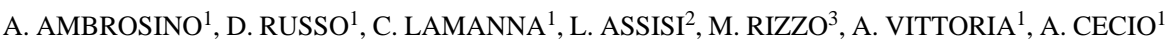 \\ ${ }^{1}$ Dept. of Biological Structures, Functions and Technology, University of Naples "Federico II", Italy \\ ${ }^{2}$ Dept. of Zoology, University of Naples "Federico II", Italy \\ ${ }^{3}$ Dept. of Paediatrics "Francesco Fede", Second University of Naples, Italy
}

Received March 4, 2003

Accepted November 29, 2003

Abstract

Ambrosino A., D. Russo, C. Lamanna, L. Assisi, M. Rizzo, A. Vittoria, A. Cecio: Isoforms of Nitric Oxide Synthase in the Pig Testis. Acta Vet. Brno 72, 2003: 493-498.

Nitric oxide is a biologically active molecule involved in the regulation of main functions of the body and is produced in different cellular types by the action of molecular isoforms of the enzyme nitric oxide synthase (NOS). The presence of the isoforms defined as neuronal, testicular, endothelial and inducible has been studied in the testis of adult pigs by means of immunohistochemical techniques. Western blot analysis and a biochemical quantitative method were also performed to confirm the morphological data and to assess nitric oxide tissue activity.

The NOS isoforms were contained in interstitial (Leydig), sustentacular (Sertoli), peritubular, endothelial and macrophage cells, as well as in spermatogonia and spermatids. Positive Leydig cells were numerous, isolated or grouped in clusters and differed in staining intensity. Testicular extracts were found to contain four types of proteins whose molecular weight was very similar to those of the NOS isoforms. The biochemical measurement of the $\mathrm{NO}_{2}$ tissue content gave the result of $155.25 \pm 21.9 \mathrm{nmol} / \mathrm{mg}$.

On the basis of a detailed bibliographic review, the findings here obtained led us to hypothesize that a) the sources of nitric oxide in the pig testis are numerous, and b) the oxide could be involved in the regulation of the following testicular functions: steroidogenesis, vasodilatation, peristalsis/permeability of seminiferous tubules and development/apoptosis of germ cells.

Pig, testis, nitric oxide synthase isoforms, testicular cytotypes

Nitric oxide (NO) is a biologically active molecule widespread diffused in the body, regulating main organic functions such as transmission of interneural impulse, secretion of hormones, motility of vascular and non-vascular smooth muscle, and immunity defence (Moncada et al. 1991; Ceccatelli et al. 1993; Murad 1994). NO is produced by the enzyme nitric oxide synthase (NOS) of which three principal isoforms were described: neuronal (nNOS), endothelial (eNOS) and inducible (iNOS) (Fostermann et al. 1991). Such isoforms have been detected, although separately, in human and rodent testicular cytotypes such as interstitial (Leydig) and sustentacular (Sertoli), peritubular, germ, endothelial and macrophage cells. They were studied mainly by applying immunohistochemical techniques to different experimental conditions, in health and diseases (Davidoff et al. 1995; S tephan et al. 1995; Grozdanovic et al. 1995; Zini et al. 1996; Lissbrant et al. 1997; Middendorff et al. 1997; Tatsumi et al. 1997; O' Bryan et al. 2000; Koziel et al. 2000; Fujisawa et al. 2001). Recently an $\mathrm{NH}_{2}$ terminal truncated nNOS has been detected in human and mouse Leydig cells in which it is encoded by the activity of a specific gene promoter. Such molecule, defined testis-nNOS (TnNOS), shows a molecular weight of $125 \mathrm{kDa}$ instead of $160 \mathrm{kDa}$ which is the weight of the full length molecule. Its biological role is still unknown (Wang et al. 1997; Wang et al. 2002).

Address for correspondence:

A. Ambrosino

Dept. of Biological Structures,

University of Naples "Federico II", Italy

E-mail: Cecio@unina.i

http://www.vfu.cz/acta-vet/actavet.htm 
In the testis NO has been thought to influence testosterone synthesis, blood circulation, seminiferous tubule contraction and germ cell metabolism/apoptosis (Adams et al. 1994; Davidoff et al. 1995; Rosselli et al. 1995; El Gohary et al. 1999). The ways by which the oxide plays these roles are incompletely understood as yet. They are related to the activation of two enzymes: cytoplasmic soluble guanylyl cyclase or mitochondrial P 450 cytochrome. A (direct or indirect) modification of gene transcription cannot be excluded (Snyder et al. 1996; Davidoff et al. 1997; Pomerantz and Pitelka 1998).

This study aimed to: a) detect the presence and distribution of the NOS isoforms in the pig testis by means of immunohistochemistry, b) determine the molecular weight of the NOS isoforms by western blotting analysis and c) assess activity of testicular NO by a biochemical method. Finally, the pig was chosen because there has been no data available in this species, and because porcine testis is particularly rich in Leydig cells.

\section{Materials and Methods}

Small samples of testis and cerebellum were collected from five Large White pigs at a local slaughterhouse, soon after the death of the animals that were fourteen to eighteen months of age. The cerebellum was chosen as a comparison organ because it is known to contain the nNOS isoform and, on the contrary, lacking of the TnNOS isoform (Wang et al. 2002). The material was processed as described below.

\footnotetext{
Immunohistochemistry
}

Samples were fixed in Bouin's fluid for 12-24 h at room temperature, dehydrated, embedded in Paraplast and cut on microtome into $7 \mu \mathrm{m}$ sections. Two indirect immunohistochemical methods were used for staining. The first employed the avidin-biotin complex (ABC) (Vector Laboratories, PK-6101) and the second utilized tyramide molecules as signal amplifiers. The latter technique was introduced into immunohistochemical practice quite recently (Adams 1992) and its sequence was as follows: primary antibody, peroxidase-labelled secondary antibody, dinitrophenol (DNP)-labelled tyramide (NEN Life Sciences, Kit NEL 747 A), HRP-conjugated anti-DNP antibody (NEN Life Sciences, Kit NEL 747 A). 3,3' diaminobenzidine (DAB) (Vector Laboratories, SK 4100) was used as chromogen for the ABC method while the complex DAB-nickel (Vector Laboratories, SK 4100) was utilized for the amplified technique. The primary antibodies were polyclonal, raised in rabbits and directed against the nNOS, eNOS and iNOS isoforms (S. Cruz Biotechnol., SC 648, SC 654, SC 651, respectively). They were diluted 1:400 and applied to the sections overnight. Control sections were incubated with PBS (0.01 M, pH 7.4) or normal rabbit serum in the specific step and never showed positivities. In particular the anti-nNOS antibody used here is directed against the - $\mathrm{COOH}$ terminal of nNOS and recognises this latter but also cross reacts with TnNOS which has the same structure of the first with the deletion of the 1-335 amino acid sequence (Alderton et al. 2001). Interstitial macrophages were identified immunohistochemically by using a monoclonal antibody raised in mouse and directed against the CD1 protein from pig leukocytes (VMRD Inc., 76-7-4). Before staining the sections were placed in citrate buffer $(0.01 \mathrm{M}, \mathrm{pH}$ 6) and heated in a microwave oven (Siemens E-Nr HF12021/01, 800 W) at maximal power for two cycles, 5 min each.

The preparations were observed by a Nikon E 600 light microscope and microphotographs were taken by using Kodak Technical Pan black/white film.

Western blotting analysis

Samples from testes were homogenized in ice cold membrane buffer (50 mM Tris- $\mathrm{HCl}, 150 \mathrm{mM} \mathrm{NaCl}, 5 \mathrm{mM}$ EDTA, $50 \mu \mathrm{g} / \mathrm{ml}$ AEBSF, $2 \mu \mathrm{g} / \mathrm{ml}$ Leupeptin, $2 \mu \mathrm{g} / \mathrm{ml}$ Aprotinin; $\mathrm{pH}$ 7.4) and centrifuged at $8000 \mathrm{rpm}$ for $15 \mathrm{~min}$ at $4{ }^{\circ} \mathrm{C}$. Protein concentration was assessed by the Bradford assay. Then $30 \mu \mathrm{g}$ of protein were diluted 1:5 in 5x SDS loading buffer ( $5 \mathrm{mM}$ Tris-HCl, 1\% SDS, 10\% glycerol, 1\% 2-Mercaptoethanol; pH 6.8), boiled for 5 min, size fractionated by SDS-PAGE on 7.5\% gel and electrophoretically transferred to PVDF membrane (Tropix A.B.; XM 105). This latter was rinsed in PBS, immersed in blocking buffer for 60 min and incubated for 90 min with the antibodies directed against the NOS isoforms (see above) previously diluted 1:400 in blocking buffer. Alkaline phosphate-conjugated goat anti-rabbit IgG (Tropix A.B.; WT 10 RC Kit) was diluted 1:5 000 in blocking buffer and applied for $60 \mathrm{~min}$, as secondary antibody. Finally the membrane was bathed in CSPD, a chemiluminescent reagent, and exposed for $30 \mathrm{sec}$ to a Kodak black/white film (Sigma; X-OMAT AR). The same procedure was used to analyse the cerebellum samples with the exception that, in this case, it was used only the antibody directed against the nNOS.

Biochemical measurement of NO activity

According to Meli et al. (1997), NO activity was assessed by measurement of tissue $\mathrm{NO}_{2}$ which is an oxidation product of NO. Samples from testes were rinsed in cold PBS buffer (0.1 M, pH 7.4) soon after collection and then weighed and homogenised $(1.2, \mathrm{w} / \mathrm{v})$ in the same ice-cold buffer. The subsequent phases were carried out at $4{ }^{\circ} \mathrm{C}$. The suspension was centrifuged at $3500 \times \mathrm{g}$ for $15 \mathrm{~min}$ and aliquots of $100 \mu \mathrm{l}$ of supernatant were mixed with aliquots of $100 \mu \mathrm{l}$ of Griess reagent containing $1 \%$ sulphanilamide and $0.1 \%$ naphthylethylenediamide in $5 \%$ 
phosphoric acid. The suspensions were kept at room temperature for $10 \mathrm{~min}$ and then their absorbance at $550 \mathrm{~nm}$ was measured in a microplate reader (Titertek multiskan MCC). Solutions of sodium nitrite $\left(\mathrm{NaNO}_{2}\right)$ served as standards. Nitrite concentration of the tissue suspensions was calculated by comparing their OD with those of the standard solutions.

The assay data were analysed by a one-way ANOVA method followed by Duncans' multirange test. Values were expressed as mean \pm SD.

\section{Results}

nNOS immunoreactivity was found in Leydig (Plate III, Figs 1a,b) and peritubular myoid cells (Fig. 1c) as well as, within the seminiferous tubules, in Sertoli cells (Fig. 1d) and spermatogonia (Fig. 1e). The positive Leydig cells were numerous and appeared isolated or grouped in clusters containing a variable number of components, from a minimum of 4-5 to a maximum of 25-30. They were roundish/polyhedric in shape, larger than the other interstitial cytotypes and different in staining intensity. Reactive peritubular and Sertoli cells and positive spermatogonia were rare and present only in part of the seminiferous tubules visible in a tissue section. The Sertoli cells were lightly stained but easily discernible due to their irregular cytoplasmic profile. eNOS immunoreactivity was detected in Leydig (Plate IV, Fig. 2a), Sertoli (Fig. 2b) and endothelial cells (Fig. 2c) as well as in spermatids (Fig. $2 d)$. These positive cells resulted infrequent with the exception of the Leydig, more numerous. Finally, iNOS immunoreactivity was found in Sertoli (Fig. 2e) and macrophage cells (Fig. 2f). The first were rare while the second were numerous and stained also by the anti-CD1 antibody (Fig. 2g). Macrophages resulted mainly isolated and polymorphic in shape, the oval profile being quite frequent. They were localized generally at the periphery of the interstitial spaces and frequently showed a perivascular position (Figs. 2f,g).

The immunohistochemical technique utilizing tyramide as a signal amplifier was largely preferred to the $\mathrm{ABC}$ complex method because of its sensitivity in revealing even small quantities of antigen.

The western blot analysis from testicular extracts showed four discrete protein bands recognised by the NOS isoform antibodies. On the basis of their electrophoretic mobility the bands had molecular weights of 160, 133, 131 and $125 \mathrm{kDa}$ respectively for nNOS, eNOS, iNOS and TnNOS (Plate III, Fig. 3). The blot analysis from cerebellar extracts was performed utilizing the anti-nNOS antibody alone and showed the presence of a unique band corresponding to the molecular weight of the nNOS protein (160 kDa) (Fig. 3).

The biochemical measurement of $\mathrm{NO}_{2}$ tissue content performed by the Meli's method, gave the result of $155.25 \pm 21.9 \mathrm{nmol} / \mathrm{mg}$.

\section{Discussion}

An accurate experimental study performed in human and mouse testis showed that, at least in these species, the TnNOS isoform is not diffuse in the organ but restricted to the Leydig cells (Wang et al. 2002). As reported above the anti-nNOS antibody used in this work cannot differentiate nNOS from TnNOS due to their high structural similarity. On the basis of such considerations and apart from interspecies differences, the positivity we obtained in the Leydig cells using such antibody should be indicative of the presence of both the molecules while those obtained elsewhere should be due to nNOS alone. Such hypothesis is supported by the finding of positive Leydig cells more numerous than the other reactive cytotypes and by the consideration that their difference in staining intensity could be due to variable amounts of the said two isoforms.

A detailed review of the bibliography showed that the three main isoforms of NOS, neuronal, endothelial and inducible, have been detected in many testicular cytotypes, i.e., Leydig, Sertoli, endothelial, peritubular and macrophage cells as well as spermatogonia, 
spermatocytes and spermatids (Davidoff et al. 1995; Grozdanovic et al. 1995; Stephan et al. 1995; Zini et al. 1996; Liss brant et al. 1997; Middendorff et al. 1997; Tatsumi et al. 1997; Koziel et al. 2000; O'Bryan et al. 2000). Although this finding was obtained from different species (man and two rodent species) and by various technical/experimental conditions, it led us to hypothesise that the mammalian testis has good potentiality of NO producing. A metabolic turn over of the NOS isoforms could also be present in the testicular cytotypes as suggested by the inconstancy of their positivity at the relative antibodies and by the existence of putative regulators of NO activity. It was reported that the cellular production of the oxide can be influenced by the presence of glutamate, aspartate, cytokines, acetylcholine, noradrenaline, serotonin, endothelin, bradykinin, lipopolysaccharides, protein kinases, hsp 90, VEGF, histamine, kalirin and PIN (Kagi et al. 1988; Garthwaite and Boulton 1995; Baader and Schilling 1996; Tatsumi et al. 1997; Banche et al. 1998; Meroni et al. 2000; Alderton et al. 2001). Some of these molecules, i.e., glutamate, aspartate, cytokine interleukin 6 , serotonin, protein kinases A, C and II have been described in the Leydig cell (Kagi et al. 1988; David off et al. 1993, 1995; Saez 1994; Tatsumi et al. 1997).

NO has been retained to play in the testis the following functions: a) inhibition of steroidogenesis, b) stimulation of germ cell metabolism/apoptosis, c) relaxation of vascular myocytes, d) regulation of peristalsis and permeability of the seminiferous tubule wall (Adams et al. 1994; Welch et al. 1995; Rosselli et al. 1995; Del Punta et al. 1996; Middendorff et al. 1997; Davidoff et al. 1997; Lissbrandt et al. 1997; Pomerantz and Pitelka 1998; El Gohary et al. 1999). The role played by NO in the steroidogenesis inhibition has primary importance in the species reproduction. It will be briefly discussed.

NO could inhibit Leydig cell testosterone synthesis directly and indirectly. In the first case NO, released within the testis by the cellular sources described above or by intraorganic nerve fibres (Zini et al. 1996), could activate soluble guanylyl cyclase (sGC) in the Leydig cell and consequently cyclic guanosin monophosphate (cGMP) (Welch et al. 1995; David off et al. 1997). This latter could induce the stimulation of a yet poorly documented cytoplasmic protein kinase (Middendorff et al. 1997). It is worthy of note that the sGC/cGMP way of cellular response to NO has been proposed not only for the Leydig cell but also for other testicular cytotypes such as Sertoli, endothelial, peritubular and germ cells (Middendorff et al. 2000). Alternatively, it has been hypothesised that the intracellular mediator of the androgenolitic action of NO is an enzyme belonging to the group of $\mathrm{P} 450$ cytochromes (Del Punta et al. 1996; Pomerantz and Pitelka 1998). Particularly the administration of the NO-donor molecule S-nitroso-N-acetyl penicillamine to cultured Leydig cells inhibited steroidogenesis by decreasing the action of the enzyme $17 \alpha$ hydroxylase $/ \mathrm{C}_{17 / 20}$ lyase (Pomerantz and Pitelka 1998). Indirect ways in which NO could act on Leydig cell steroidogenesis are the dilation of testis microvasculature, and consecutive stasis of blood circulation (Zini et al. 1996), and inhibition of LH synthesis/secretion by the gonadotrope-releasing cells of the hypophysis in which NO has been found to be produced (Ceccatelli et al. 1993).

A recent study on the action of $\mathrm{NO}$ on Leydig cell steroidogenesis reports that the effect of the oxide could be considered biphasic resulting in a stimulation at low concentration and in an inhibition at high concentration (Valenti et al. 1999).

The other functions played by NO in the testis are poorly known and mainly derived from analogous findings obtained in other organs. Recently the presence of the eNOS and iNOS in the Sertoli cell has been related, respectively, to the interaction with germ cells (Fujis aw a et al. 2001) and to the production of gamma-glutamyl transpeptidase (Meroni et al. 2000). This enzyme activates amino acid transport across the plasma membrane and regulates glutathione levels. 
The western blot analysis from pig testicular extracts showed the existence of four types of proteins whose molecular weights, $160,133,131$ and $125 \mathrm{kDa}$, are identical to those of the NOS isoforms, neuronal, endothelial, inducible and testicular, respectively. This latter lacks from the cerebellar extracts. Such findings and that obtained from the measurement of NO activity confirm the validity of the immunohistochemical data obtained and strengthen the hypothesis that the pig testis produces NO.

In conclusion it is probable that: a) NO is produced by various cytotypes in the testis; b) it acts on cellular targets, regulating some testicular functions; c) it is a component of the molecular complex contained in the Leydig cell which cooperates with exogenous hormones to regulate the androgen production.

\section{Izoformy NO syntázy ve varlatech prasat}

NO je biologicky aktivní molekula účastnící se základních funkcí v těle a je produkována $\mathrm{v}$ různých typech buněk činností izoforem enzymu NO syntázy (NOS). Přítomnost izoforem definovaných jako neuronové, testikulární, endoteliální a inducibilní byla studována ve varlatech dospělých kanců pomocí imunohistochemických postupů. Analýza Western blot a biochemická kvantitativní metoda byly rovněž použity k potvrzení morfologických údajů a k stanovení NO-tkáňové aktivity.

Izoformy NOS byly obsaženy v buňkách Leydigových, Sertoliho, peritubulárních, endoteliálních a v makrofázích, jakož i v spermatogoniích a spermatidách. Pozitivní Leydigovy buňky byly četné, izolované nebo ve shlucích a lišily se intenzitou zabarvení. V extraktech z varlat byly zjištěny 4 typy proteinů, jejichž molekulová hmotnost byla velmi podobná té NOS izoforem. Biochemickými měřeními obsahu $\mathrm{NO}_{2} v$ tkáni se dospělo k výsledku 155.25 $\pm 21.9 \mathrm{nmol} / \mathrm{mg}$.

Na základě důkladného prostudování literatury a vlastních nálezů lze předpokládat, že a) zdrojů NO v kančích varlatech je několik a b) oxid dusíku se může účastnit regulace následujících testikulárních funkcí: tvorba steroidů, vasodilatace, peristaltika/permeabilita semenotvorných kanálků a vývoj/apoptóza zárodečných buněk.

\section{References}

ADAMS, JC 1992: Biotin amplification of biotin and horseradish peroxidase signals in histochemical stains. J Histochem Cytochem 40: 1457-1463

ADAMS, ML, MEYER, ER, SEWING, BN, CICERO, TJ 1994: Effects of nitric oxide-related agents on rat testicular function. J Pharmacol exp Ther 269: 230-237

ALDERTON, WK, COOPER, CE, KNOWLES, RG 2001: Nitric oxide synthase: structure, function and inhibition. Biochem J 357: 593-615

BAADER, SL, SCHILLING, K 1996: Glutamate receptors mediate dynamic regulation of nitric oxide synthase expression in cerebellar granule cells. J Neurosci 16: 1440-1449

BANCHE, F, STEPHAN, JP, TOUZALIN, AM, JEGOV, B 1998: In vitro regulation of an inducible-type NO synthase in the rat seminiferous tubule cells. Biol Reprod 58: 431-438.

CECCATELLI, S, HULTING, AL, ZHANG, X, GUSTAFSSON, L, VILLAR, M, HOKFELT, T 1993: Nitric oxide synthase in the rat anterior pituitary gland and the role of nitric oxide in the regulation of luteinizing hormone secretion. Proc Natl Acad Sci 90: 11292-11296

DAVIDOFF, MS, MIDDENDORFF, R, MAYER, B, DE VENTE, J, KOESLING, D, HOLSTEIN, AF 1997: Nitric oxide/cGMP pathway components in the Leydig cells of the human testis. Cell Tiss Res 287: $161-170$

DAVIDOFF, MS, MIDDENDORFF, R, MAYER, B, HOLSTEIN, AF 1995: Nitric oxide (NOS-I) in Leydig cells of the human testis. Arch Histol Cytol 58: 17-30

DAVIDOFF, MS, SCHULZE, W, MIDDENDORFF, R, HOLSTEIN, AF 1993: The Leydig cells of the human testis - a new member of the diffuse neuroendocrine system. Cell Tiss Res 271: 429-439

DEL PUNTA, K, CHARREAU, EH, PIGNATARO, OP 1996: Nitric oxide inhibits Leydig cell steroidogenesis. Endocrinol 137: 5337-5343

EL-GOHARY, M, AWARA, WM, NASSAR, S, HAWAS, S 1999: Deltamethrin-induced testicular apoptosis in rats: the protective effect of nitric oxide synthase inhibitor. Toxicol 132: 1-8 
FORSTERMANN, U, SCHIMDT, HHHW, POLLOCK, JS, SHANG, H, MITCHELL, JA, WARMER, TD, NAKANE, M, MURAD, F 1991: Isoforms of nitric oxide synthase, characterization and purification from different cell types. Biochem Pharmacol 42: 1849-1857

FUJISAWA, M, YAMANAKA, K, TANAKA, H, OKADA, H, ARAKAWA, S, KAMIDONO, S 2001: Expression of endothelial nitric oxide synthase in the Sertoli cells of men with infertility of various causes. BJU Int 87: 85-88

GARTHWAITE, J, BOULTON, CL 1995: Nitric oxide signalling in the central nervous system. Ann Rev Physiol 57: $683-706$

GROZDANOVIC, Z, NAKOS, G, MAYER, B, GOSSRAN, R 1995: A modified method allows for correlation between NADPH-diaphorase histochemistry and immunohistochemistry for the demonstration of neuronal nitric oxide synthase (nNOS). Folia Histochem Cytobiol 33: 11-18

KAGI, U, CHAFOULEAS, JG, NORMAN, AW, HEIZMANN, CW 1988: Developmental appearance of the $\mathrm{Ca}^{2+}$ binding proteins parvalbumin, calbindin D-28K, S-100 proteins and calmodulin during testicular development in the rat. Cell Tiss Res 252: 359-365

KOZIEL, E, KOTULA, M, ANDRONOWSKA, A, PIERSCHINSKI, A, BILINSKA, B 2000: Correlation between NADPH-diaphorase and iNOS in bank vole Leydig cells in vitro and in testicular sections with use of histochemistry and immunohistochemistry. Folia Histochem Cytobiol 38: 71-78

LISSBRANT, E, LÖFMARK, U, COLLIN, O, BERGH, A 1997: Is nitric oxide involved in the regulation of the rat testicular vasculature? Biol Reprod 56: 1221-1227

MELI, R, MATTAN RASO, G, GUALILLO, O, PACILIO, M, DI CARLO, R 1997: Prolactin modulation of nitrite oxide and TNF- $\alpha$ production by peripheral neutrophils in rats. Life Sci 61: 1395-1403

MERONI, SB, SUBURO, AM, CIGORRAGA, SB 2000: Interleukin-1 beta regulates nitric oxide production and gamma-glutamyl transpeptidase activity in Sertoli cells. J Androl 21: 855-861

MIDDENDORFF, R, DAVIDOFF, MS, BEHERENDS, S, MEWE, M, MIETHENS, A, MÜLLER, D 2000: Multiple roles of the messenger molecule cGMP in testicular function. Androl 32: 55-59

MIDDENDORFF, R, MÜLLER, D, PAUST, HJ, HOLSTEIN, AF, DAVIDOFF, MS 1997: New aspects of Leydig cell function. Adv exp Med Biol 424: 125-138

MONCADA, S, PALMER, RMJ, HIGGS, EA 1991: Nitric oxide: physiology, pathophysiology and pharmacology. Pharmacol Rev 43: 109-142

MURAD, F 1994: The nitric oxide-cyclic GMP signal transduction system for intracellular and intercellular communication. Rec Progr Horm Res 49:239-248

O'BRYAN, MK, SCHLATT, S, GERDPRASERT, O, PHILLIPS, DJ, DE KRETSER, DM, HEDGER, MP 2000: Inducible Nitric Oxide Synthase in the rat testis: evidence for potential roles in both normal function and inflammation-mediated infertility. Biol Reprod 63: 1285-1293

POMERANTZ, DK, PITELKA, V 1998: Nitric oxide is a mediator of the inhibitory effect of activated macrophages on production of androgen by the Leydig cell of the mouse. Endocrinol 139: 922-931

ROSSELLI, M, DUBEY, RK, IMTHURM, B, MACAS, E, KELLER, PJ 1995: Effects of nitric oxide on human spermatozoa: evidence that nitric oxide decreased sperm motility and induced sperm toxicity. Human Reprod 10: $1786-1790$

SAEZ, JM 1994: Leydig cells: endocrine, paracrine, and autocrine regulation. Endocr Rev 15: 574-626

SNYDER, GD, HOLMES, RW, BATES, JM, VAN VOORHIS, BJ 1996: Nitric oxide inhibits aromatase activity: mechanism of action. J Steroid Biochem Molec Biol 58: 63-69

STEPHAN, JP, GUILLEMOIS, C, JEGOV, B, BANCHE, F 1995: Nitric oxide production by Sertoli cells in response to cytokines and lipopolysaccharide. Biochem Biophys Res Commun 213: 218-224

TATSUMI, N, FUJISAWA, M, KANZAKI, M, OKUDA, Y, OKADA, H, ARAKAWA, S, KAMIDONO, S 1997: Nitric oxide production by cultured rat Leydig cells. Endocrinol 138: 994-998

VALENTI, S, CUTTICA, CM, FAZZUOLI, L, GIORDANO, G, GIUSTI, M 1999: Biphasic effect of nitric oxide on testosterone and cyclic GMP production by purified rat Leydig cells cultured in vitro. Int J Androl 22: 336341

WANG, Y, GOLIGORSKY, MS, LIN, M, WILCOX, JN, MARSDEN, PA 1997: A novel, testis-specific mRNA transcript encoding an $\mathrm{NH}_{2}$-terminal truncated nitric oxide synthase. J Biol Chem 272: 11392-11401

WANG, Y, NEWTON, DC, MILLER, TL, TEICHERT, AM, PHILLIPS, MJ, DAVIDOFF, MS, MARSDEN, PA 2002: An alternative promoter of the human neuronal nitric oxide synthase gene is expressed specifically in Leydig cells. Am J Pathol 160: 369-380

WELCH, C, WATSON, ME, POTH, M, HONG, T, FRANCIS, GL 1995: Evidence to suggest nitric oxide is an interstitial regulator of Leydig cell steroidogenesis. Metab 44: 234-238

ZINI, A, O'BRYAN, MK, MAGID, MS, SCHLEGEL, PN 1996: Immunohistochemical localization of endothelial nitric oxide synthase in the human testis, epididymis, and vas deferens suggests a possible role for nitric oxide in spermatogenesis, sperm maturation, and programmed cell death. Biol Reprod 55: 935-941 
Plate III

Ambrosino A. et al.: Isoforms... pp. 493-498

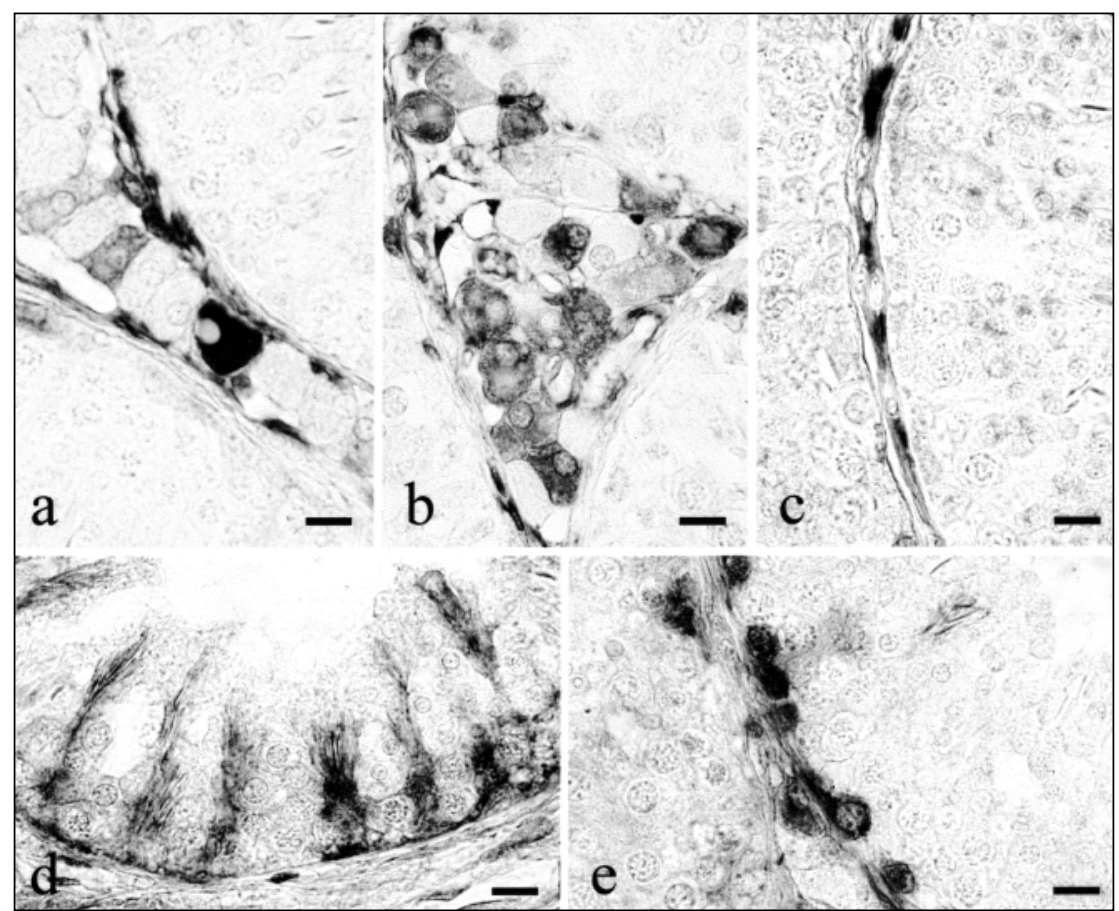

Fig. 1. Immunoreactivity for nNOS. a,b: isolated (a) and clustered (b) Leydig cells in two interstitial spaces. Note the roundish/polyhedric shape and the different staining intensities. c: myoid cells aligned at the boundary of a seminiferous tubule. d: Sertoli cells typically elongated and irregular in shape. e: several reactive spermatogonia localised at the basal side of the germinal epithelium. TSA amplified technique. Bars: $10 \mu \mathrm{m}$.

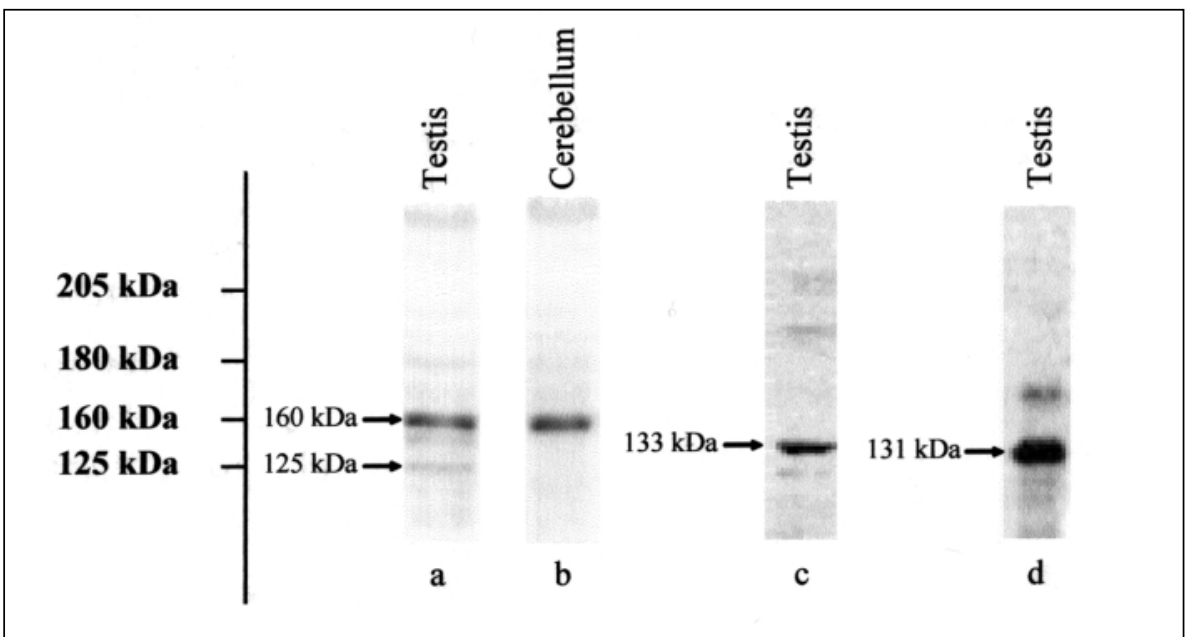

Fig. 3. Western blot detection of NOS immunoreactivity in homogenates from pig testis and cerebellum. a: the anti-nNOS antibody recognised in testis homogenates two protein bands corresponding to the molecular weights of nNOS $(160 \mathrm{kDa})$ and TnNOS $(125 \mathrm{kDa})$, respectively. b: the same antibody recognised in cerebellum extracts the $160 \mathrm{kDa}$ band alone. c,d: the antibodies directed against eNOS (c) and iNOS (d) detected the presence of the respective antigens (133 and $131 \mathrm{kDa}$ ) in testis homogenates. 


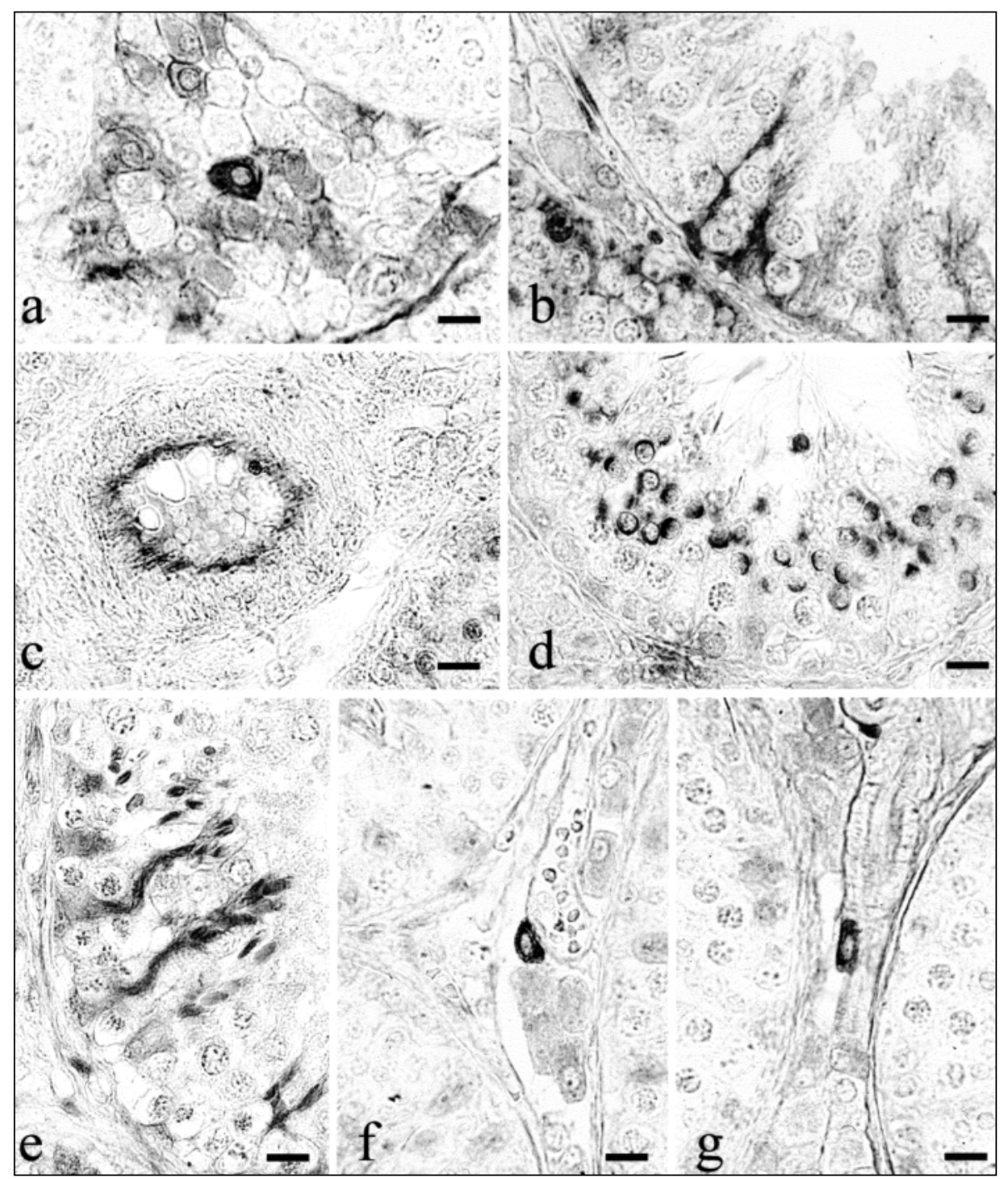

Fig. 2. Immunoreactivity for eNOS (a-d), iNOS (e, f) and CD1 (g). a: an interstitial space filled with negative and differently stained Leydig cells. b: a couple of Sertoli cells packed between piles of spermatocytes. $c$ : endothelial cells found in a small sized blood vessel. d: roundish spermatids showing intense staining in the acrosomal zone. e,f: Sertoli cells (e) and an isolated macrophage (f) containing the iNOS isoform. g: fusiform shaped macrophages, although mainly isolated, are quite frequent in the interstitial spaces. Figs. a to e: TSA amplified technique; figs. f, g: ABC method. Bars: $10 \mu \mathrm{m}$. 